\title{
PERGAMON
}

www.elsevier.com/locate/watres

\section{RESIDUE CHARACTERISTICS AND PORE DEVELOPMENT OF PETROCHEMICAL INDUSTRY SLUDGE PYROLYSIS}

\author{
HUNG-LUNG CHIANG ${ }^{1 *}$, CHING-GUAN CHAO ${ }^{1}$, C. Y. CHANG ${ }^{2}$, C. F. WANG ${ }^{2}$ \\ and P. C. CHIANG ${ }^{3}$ \\ ${ }^{1}$ Department of Environmental Engineering, Fooyin Institute of Technology, Kaoshsiung Hsien, Taiwan, \\ ROC; ${ }^{2}$ Department of Nuclear Science, National Tsing Hua University, Hsinchu, Taiwan and ${ }^{3}$ Graduate \\ Institute of Environmental Engineering, National Taiwan University, Taipei, Taiwan, ROC
}

(First received 13 October 2000; accepted in revised form 12 March 2001)

\begin{abstract}
Petrochemical industry bio-sludge was pyrolyzed to investigate the composition and pore size distribution of pyrolytic residue. Results indicated that the carbon, nitrogen, and hydrogen concentrations could be reduced after an increase in pyrolytic temperature. The trace element analysis indicated that $\mathrm{Al}$, $\mathrm{Ca}, \mathrm{Fe}, \mathrm{Mg}, \mathrm{K}, \mathrm{Cu}, \mathrm{Sr}$, and $\mathrm{Sb}$ concentrated during the pyrolytic process. When forty grams of pre-dried sludge were pyrolyzed at various pyrolytic temperatures, the transfers from the gas phase to liquid phase to residue were from 21.2 to $36.0 \%$, from 49.0 to $70.0 \%$, and from 8.3 to $16.5 \%$. Results of the pore size distribution examination indicated that the mesopore had the greatest effect on the bio-sludge pyrolysis. The optimal pyrolytic temperatures and times were approximately $800^{\circ} \mathrm{C}$ for $30 \mathrm{~min}$ and $900^{\circ} \mathrm{C}$ for $10 \mathrm{~min}$. The conceptual model can reasonably explain the pore structure development during the pyrolysis process. (C) 2001 Elsevier Science Ltd. All rights reserved
\end{abstract}

Key words - biosludge, pyrolysis, pore size distribution, element composition, petrochemical industry

\section{INTRODUCTION}

In Taiwan, 74,150 ton of sludge were produced from industrial parks in 1998 (Taiwan EPA, 1999). Sludge was treated by landfill $(33.9 \%)$, compost $(1.2 \%)$, incineration $(27.9 \%)$, recycled for brick $(37.0 \%)$, and solidified $(0.04 \%)$ (Taiwan EPA, 1999). A great deal of money was required for disposal. Over one-third of the sewage sludge was recycled. According to baseline information, sludge can be recycled from the incineration treatment process in Taiwan.

The reuse of digested sludge on farmland is limited by the uptake capacity of the soil and the high concentration of toxic organic constituents and heavy metals (Dumpelmann et al., 1991). Additionally, in many countries like Taiwan, landfill treatment is limited by land cost and insufficient land. Incineration provides a large volume reduction and results in improved energy efficiency, although the scrubbing cost of the exhaust gas is high. The pyrolysis of sewage sludge in an oxygen-free atmosphere in fluidized beds has been proposed by Kaminsky (1989). Work that has been carried out by Piskorz et al. (1986) achieved high liquid yields. These were obtained by a short residence time $(0.55 \mathrm{~s})$

*Author to whom all correspondence should be addressed. Fax: + 886-7-7829117; e-mail: hlchiang@mail.fy.edu.tw and medium temperature $\left(450^{\circ} \mathrm{C}\right)$. Bayer and Kutubuddin (1987) and Briddle (1982) used rotary kilns at low temperatures $\left(250-450^{\circ} \mathrm{C}\right)$ to generate maximum liquid products. Pyrolytic residues, i.e. the char, can be used as an adsorbent if pyrolyzed under controlled conditions or with some chemical treatment (Chiang and You, 1987).

Kim et al. (1996) investigated the technical feasibility of converting paint sludge to activated char and reusing the char in paint solvent adsorption. $\mathrm{Lu}$ et al. (1995) investigated the surface area development of sewage sludge during the pyrolytic process.

In this work, we focused on the elemental composition and pore size distribution of the pyrolytic residue of sludge, which was taken from a petrochemical wastewater treatment plant and pyrolyzed in a nitrogen atmosphere. Various temperatures and times were used. The chemical composition, BET (Brubauer, Emmett, and Teller) surface area, and residue pore size distribution were measured.

\section{EXPERIMENTAL}

\section{Raw material}

The sludge sample was obtained from a petrochemical wastewater treatment plant in Kaohsiung, Taiwan. The 
sludge cake of about $300 \mathrm{~kg}$ was sampled at one time to avoid varying sludge characteristics. Sludge was stored at $4{ }^{\circ} \mathrm{C}$ until pyrolyzed. Two kilograms of the sludge sample were dried in an oven at $105^{\circ} \mathrm{C}$ for $24 \mathrm{~h}$ in each run. Raw activated sludge cakes had a total solids (TS) content of $12.7 \pm 1.2 \mathrm{wt} \%$ and a volatile solids (VS) concentration of $73.5 \pm 4.3 \mathrm{wt} \%$. The sludge cake was conditioned and dried at $378 \mathrm{~K}$. Carbon, oxygen, hydrogen, nitrogen and sulfur concentrations were $39.0,24.4,5.70,4.75$, and $1.18 \%$.

\section{Pyrolysis process}

Pyrolysis was carried out in an isothermal reactor heated by a horizontal electric furnace. At the beginning of each run, $40 \mathrm{~g}$ of pretreated sewage sludge (irregularly spherical shape, diameter: $1.0-1.5 \mathrm{~cm}$ ) was placed in the middle of a quartz tube internal diameter (I.D.) $30 \mathrm{~mm}$ and length $70 \mathrm{~cm})$. High purity $(99.995 \%)$ nitrogen was used as the purging gas, which flowed through the sample bed at $2 \mathrm{~L} /$ min. The reactor was heated to the designated temperature at $15 \mathrm{~K} / \mathrm{min}$. The pyrolysis temperatures and the sample residence times varied from 400 to $900^{\circ} \mathrm{C}(400,500,600$, 700,800 , and $900^{\circ} \mathrm{C}$ ) and from 3 to $90 \mathrm{~min}(3,5,10,15,20$, $25,30,60$, and $90 \mathrm{~min})$. Each experiment was run with one pyrolytic temperature at four to five different pyrolytic times. After pyrolysis, the reactor was cooled down to room temperature before the pyrolysis residue was removed for quantification and characterization. The amount of sludge pyrolysis residue was weighed on an analytical balance (Mettler-Toledo, model AB204-S, Switzerland, weighing limit is less than $0.1 \mathrm{mg}$ ).

\section{Chemical compositions of residue}

To obtain a stabilized pyrolysis residue weight, $30 \mathrm{~min}$ was chosen as the optimal pyrolysis time in these experiments. The nitrogen, carbon, hydrogen, and oxygen constituents were analyzed with an element analyzer (Heraeus CHN-O Rapid Element analyzer, USA). Sulfur and chloride concentrations were measured with the Tacussel Coloumax 78 (USA) element analyzer. Sulfanilic acid and 1-chloro-2, 4-dinitrobenzene were used as standards.
The pyrolysis residue was digested with a mixture of $\mathrm{HNO}_{3}: \mathrm{HClO}_{4}: \mathrm{HF}$ in a $3: 5: 2$ proportion. ICP-AES and ICP-MS analyzed the sludge pyrolysis residue for $\mathrm{Sr}, \mathrm{As}, \mathrm{Cr}, \mathrm{Ba}, \mathrm{Mn}, \mathrm{Ni}, \mathrm{V}, \mathrm{Se}, \mathrm{Cd}, \mathrm{Sb}, \mathrm{Al}, \mathrm{Ca}, \mathrm{Fe}, \mathrm{Na}, \mathrm{Mg}$, $\mathrm{K}, \mathrm{S}, \mathrm{Zn}, \mathrm{Pb}$, and $\mathrm{Cu}$. Analysis was performed on five samples in duplicate for quality assurance and quality control.

\section{Pore size distribution of pyrolytic residue}

The pyrolytic residue samples were placed in a vacuum oven $\left(10^{-2}-10^{-3} \mathrm{mmHg}, 105^{\circ} \mathrm{C}\right)$ and dried for $24 \mathrm{~h}$. The physical characteristics of the pyrolytic residues, including specific surface area, micropore area, total pore volume, micropore volume, pore size distribution and pore diameter were measured with $\mathrm{N}_{2}$ (g) adsorption (ASAP 2010 Pore Structure Analyzer, Micromeritrics Inc., USA) at $77 \mathrm{~K}$ with liquid $\mathrm{N}_{2}$. The BET surface area, micropore surface area, total pore volume, and micropore volume were calculated by the BET method (Brubauer et al., 1938), the BET surface area minus external surface area BJH method (Barrett et al., 1951), the $t$-plot method (Lippens and de Boer, 1965) and the Harkins-Jura method (Harkins and Jura, 1944).

\section{RESULTS AND DISCUSSION}

\section{Element compositions of sludge and residue}

Major element composition of sludge and residue. The oven dried sludge and the pyrolytic residues were analyzed for carbon, hydrogen, nitrogen, oxygen, sulfur, and chlorine. Constituents are listed in Fig. 1. Chlorine was not detected in any residue or sludge. The percentage of each element in the pyrolysis residue was less than that of the oven-dried sludge. When pyrolytic temperatures increased, the total elemental content decreased. The rate of transformation decreased at temperatures greater than $500^{\circ} \mathrm{C}$. The results also revealed that the amount of

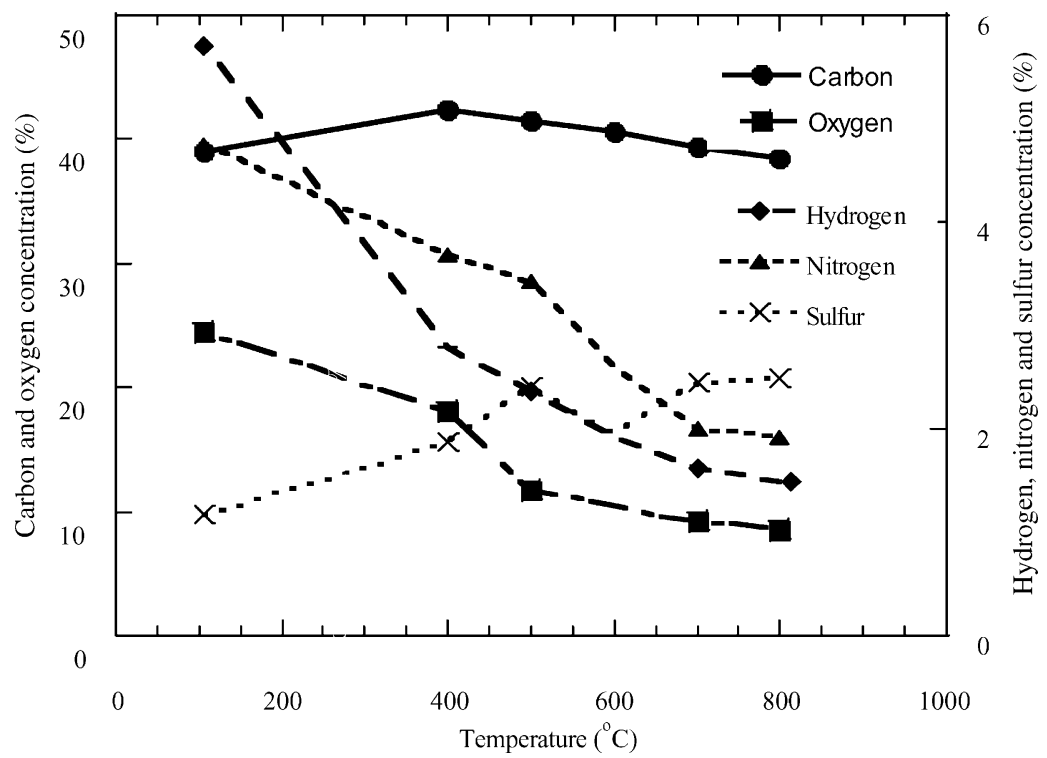

Fig. 1. Major element compositions of sludge residue at different pyrolysis temperatures. 
carbon, nitrogen, hydrogen, and oxygen from the residues decreased when the pyrolysis temperature was raised from 400 to $800^{\circ} \mathrm{C}$, suggesting that the carbon, nitrogen, hydrogen, and oxygen were desorbed but sulfur was not.

Trace element compositions of sludge pyrolysis residue. Results of the element composition in the sludge pyrolysis residue are summarized in Table 1 . When the pyrolysis temperatures ranged from 400 to $800^{\circ} \mathrm{C}$, the $\mathrm{Al}, \mathrm{Ca}, \mathrm{Fe}, \mathrm{Mg}, \mathrm{K}, \mathrm{Zn}, \mathrm{Cu}, \mathrm{Sr}, \mathrm{Sb}$ and $\mathrm{Cd}$ concentrations ranged from 20 to $33 \mathrm{mg} / \mathrm{g}, 23$ to $40 \mathrm{mg} / \mathrm{g}, 8.6$. to $16 \mathrm{mg} / \mathrm{g}, 4.2$ to $7.2 \mathrm{mg} / \mathrm{g}, 11$ to $18 \mathrm{mg} /$ g, 3.6 to $5.1 \mathrm{mg} / \mathrm{g}, 0.05$ to $0.09 \mathrm{mg} / \mathrm{g}, 207$ to $315 \mu \mathrm{g} / \mathrm{g}$, from 2.4 to $9.59 \mu \mathrm{g} / \mathrm{g}$, and from 0.17 to $0.52 \mu \mathrm{g} / \mathrm{g}$, respectively. Pyrolysis increased the $\mathrm{Al}, \mathrm{Ca}, \mathrm{Fe}, \mathrm{Mg}$, $\mathrm{K}, \mathrm{Cu}, \mathrm{Sr}$ and $\mathrm{Sb}$ concentrations. The $\mathrm{Cd}$ concentration decreased because it was volatile at temperatures higher than $600^{\circ} \mathrm{C}$. The elemental compositions decreased correspondingly to the pyrolytic temperature increases. The concentrations varied in the residue because different elemental complexes (i.e. $\mathrm{OH}^{-}, \mathrm{S}^{2-}, \mathrm{Cl}^{-}, \mathrm{CO}_{3}^{2-}, \mathrm{NO}_{3}^{-}$and $\mathrm{SO}_{4}^{2-}$ ) could not be completely digested in the $\mathrm{HNO}_{3}: \mathrm{HClO}_{4}: \mathrm{HF}$ solution or analyzed by ICPAES and ICP-MS.

\section{Mass balance of sludge pyrolysis}

Water vapor and some volatile compounds $(1365 \mathrm{~g})$ were volatilized from the original $2000 \mathrm{~g}$ by a dewatering process. Resultant dry sludge was $635 \pm 61 \mathrm{~g}$. Forty grams of the dry sludge produced 19.6 to $28.0 \mathrm{~g}$ liquid product (water and crude oil) and a pyrolyzed sludge residue of 6.0 to $3.3 \mathrm{~g}$. The dry sludge was transformed into a liquid phase (water and crude oil), solid phase (sludge residue), and gas phase (water vapor, $\mathrm{CO}, \mathrm{CO}_{2}$, $\mathrm{H}_{2}$, methanol, and other volatile compounds) by the pyrolysis process. The dry sludge that was pyrolyzed and transferred into the gas phase yielded $14.4,9.8,9.2,8.5$ and $9.1 \mathrm{~g}$ when pyrolyzed at 400 , $500,600,700$ and $800^{\circ} \mathrm{C}$, respectively. Elements of the pyrolysis sludge residue $(\mathrm{C}, \mathrm{H}, \mathrm{N}, \mathrm{O}, \mathrm{S}, \mathrm{Cl}, \mathrm{Sr}$, As, Cr, Ba, Mn, Ni, V, Se, Cd, Sb, Al, Ca, Fe, Na, $\mathrm{Mg}, \mathrm{K}, \mathrm{Zn}, \mathrm{Pb}$, and $\mathrm{Cu}$ ) decreased from 75.1 to $54.7 \%$ (Fig. 2).

\section{Surface development of pyrolytic residue}

Physical characteristics. Table 2 details the surface characteristics of the pyrolytic residue. Increasing pyrolytic temperatures heightened the BET surface area. Data indicate that the highest BET pyrolytic residue surface area was obtained when the temperature and time were in the vicinity of $800^{\circ} \mathrm{C}$ and $30 \mathrm{~min}$.

Figure 3 shows that the nitrogen adsorption isotherm $(77 \mathrm{~K})$ of the sludge pyrolyzed at various temperatures are typically type II, indicating a

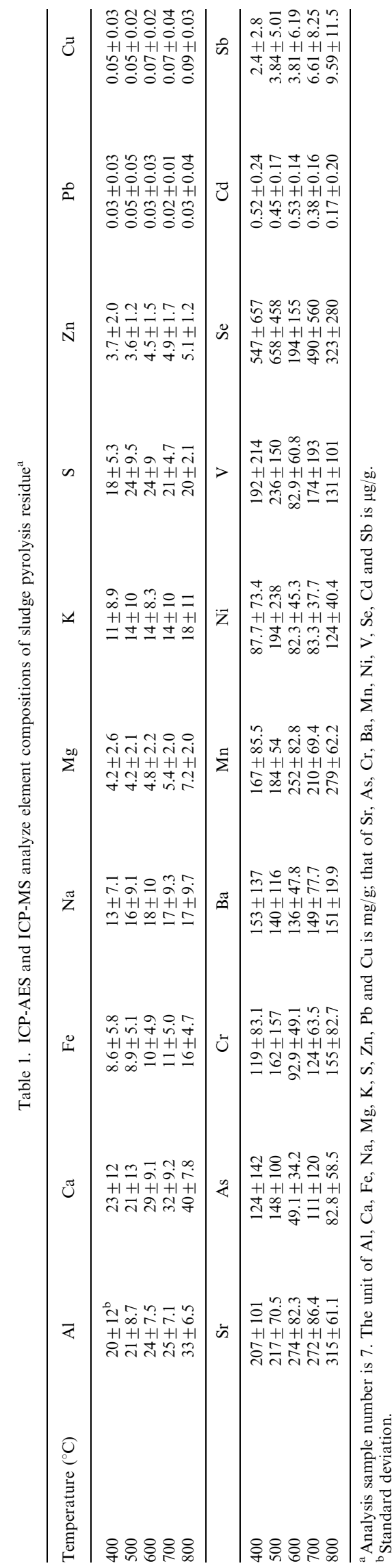


Table 2. Pore size distribution of sludge pyrolytic residue

\begin{tabular}{|c|c|c|c|c|c|c|c|c|c|c|c|}
\hline \multirow[t]{2}{*}{ Temperature $\left({ }^{\circ} \mathrm{C}\right)$} & \multirow[t]{2}{*}{ Time (min) } & \multirow{2}{*}{$\begin{array}{l}\text { BET surface } \\
\text { area }\left(\mathrm{m}^{2} / \mathrm{g}\right)\end{array}$} & \multirow{2}{*}{$\begin{array}{l}\text { Average pore } \\
\text { diameter }(\AA)\end{array}$} & \multicolumn{4}{|c|}{ Pore size distribution $\left(\mathrm{cm}^{3} / \mathrm{g}\right)$} & \multicolumn{3}{|c|}{ Percentage of pore size $(\%)$} & \multirow[t]{2}{*}{ Micropore area $\left(\mathrm{m}^{2} / \mathrm{g}\right)$} \\
\hline & & & & Macropore & Mesopore & Micropore & Total pore volume & Macropore & Mesopore & Micropore & \\
\hline \multirow[t]{4}{*}{400} & 15 & 2.77 & 92.58 & 0.0034 & 0.0061 & 0.0002 & 0.0098 & 35.1 & 62.7 & 2.2 & ND \\
\hline & 25 & 5.12 & 71.47 & 0.0030 & 0.0092 & 0.0002 & 0.0124 & 24.4 & 74.2 & 1.4 & ND \\
\hline & 60 & 7.23 & 55.00 & 0.0022 & 0.0091 & 0.0003 & 0.0116 & 19.0 & 78.5 & 2.5 & ND \\
\hline & 90 & 10.69 & 61.08 & 0.0171 & 0.0145 & 0.0012 & 0.0328 & 51.9 & 44.3 & 3.8 & ND \\
\hline \multirow[t]{5}{*}{500} & 3 & 5.19 & 36.91 & 0.0007 & 0.0047 & 0.0004 & 0.0058 & 12.3 & 81.1 & 6.6 & ND \\
\hline & 10 & 6.69 & 57.09 & 0.0019 & 0.0092 & 0.0005 & 0.0117 & 16.0 & 79.3 & 4.6 & ND \\
\hline & 20 & 10.51 & 60.56 & 0.0029 & 0.0151 & 0.0010 & 0.0190 & 15.1 & 79.5 & 5.5 & ND \\
\hline & 30 & 13.26 & 54.10 & 0.0030 & 0.0181 & 0.0005 & 0.0216 & 13.8 & 83.8 & 2.4 & ND \\
\hline & 60 & 9.32 & 58.32 & 0.0021 & 0.0149 & 0.0009 & 0.0179 & 11.9 & 83.1 & 5.0 & ND \\
\hline \multirow[t]{6}{*}{600} & 3 & 1.42 & 54.90 & 0.0004 & 0.0018 & 0.0001 & 0.0023 & 16.1 & 79.8 & 4.2 & ND \\
\hline & 10 & 7.26 & 84.11 & 0.0057 & 0.0148 & 0.0005 & 0.0210 & 27.3 & 70.3 & 2.4 & ND \\
\hline & 15 & 10.41 & 59.13 & 0.0028 & 0.0146 & 0.0011 & 0.0185 & 15.2 & 79.0 & 5.8 & ND \\
\hline & 25 & 10.14 & 60.35 & 0.0031 & 0.0146 & 0.0010 & 0.0187 & 16.5 & 78.1 & 5.4 & ND \\
\hline & 30 & 5.18 & 92.34 & 0.0063 & 0.0117 & 0.0002 & 0.0181 & 34.6 & 64.4 & 1.1 & ND \\
\hline & 60 & 5.97 & 83.9 & 0.0066 & 0.0115 & 0.0002 & 0.0184 & 36.1 & 62.8 & 1.2 & ND \\
\hline \multirow[t]{6}{*}{700} & 3 & 4.31 & 85.3 & 0.0045 & 0.0125 & 0.0004 & 0.0174 & 25.9 & 71.8 & 2.3 & ND \\
\hline & 10 & 6.94 & 70.31 & 0.0086 & 0.0134 & 0.0006 & 0.0226 & 38.1 & 59.3 & 2.7 & ND \\
\hline & 15 & 7.47 & 78.1 & 0.0084 & 0.0138 & 0.006 & 0.0228 & 36.7 & 60.5 & 2.8 & ND \\
\hline & 20 & 13.3 & 57.4 & 0.0205 & 0.0193 & 0 & 0.0398 & 51.6 & 48.4 & 0 & ND \\
\hline & 30 & 8.86 & 80.0 & 0.0095 & 0.0171 & 0.0005 & 0.0272 & 35.0 & 63.0 & 2.0 & ND \\
\hline & 60 & 7.86 & 72.31 & 0.0028 & 0.0133 & 0.0010 & 0.0171 & 16.3 & 77.8 & 5.9 & ND \\
\hline \multirow[t]{5}{*}{800} & 3 & 9.01 & 83.87 & 0.0090 & 0.0183 & 0.0005 & 0.0279 & 32.4 & 65.8 & 2.5 & ND \\
\hline & 10 & 18.63 & 62.41 & 0.0056 & 0.0292 & 0.0012 & 0.0359 & 15.5 & 81.1 & 3.4 & ND \\
\hline & 25 & 43.02 & 38.47 & 0.0075 & 0.0320 & 0.0009 & 0.0405 & 18.7 & 79.1 & 2.3 & 13.04 \\
\hline & 30 & 37.92 & 55.88 & 0.0154 & 0.0460 & 0.0007 & 0.0621 & 24.8 & 74.1 & 1.1 & 11.20 \\
\hline & 60 & 28.62 & 50.32 & 0.0322 & 0.0256 & 0.0010 & 0.0588 & 54.7 & 43.6 & 1.8 & 5.63 \\
\hline \multirow[t]{5}{*}{900} & 3 & 11.64 & 66.36 & 0.0292 & 0.0176 & 0.0011 & 0.0479 & 61.0 & 36.7 & 2.3 & ND \\
\hline & 5 & 15.51 & 71.47 & 0.0104 & 0.0264 & 0.0005 & 0.0373 & 27.8 & 70.9 & 1.3 & 0.27 \\
\hline & 10 & 40.32 & 32.26 & 0.0066 & 0.0248 & 0.0011 & 0.0326 & 20.3 & 76.2 & 3.5 & 13.98 \\
\hline & 30 & 34.87 & 71.96 & 0.0083 & 0.0645 & 0 & 0.0727 & 11.4 & 88.6 & 0.0 & ND \\
\hline & 60 & 29.80 & 85.34 & 0.0062 & 0.0324 & 0.0005 & 0.0391 & 15.9 & 82.9 & 1.3 & ND \\
\hline
\end{tabular}




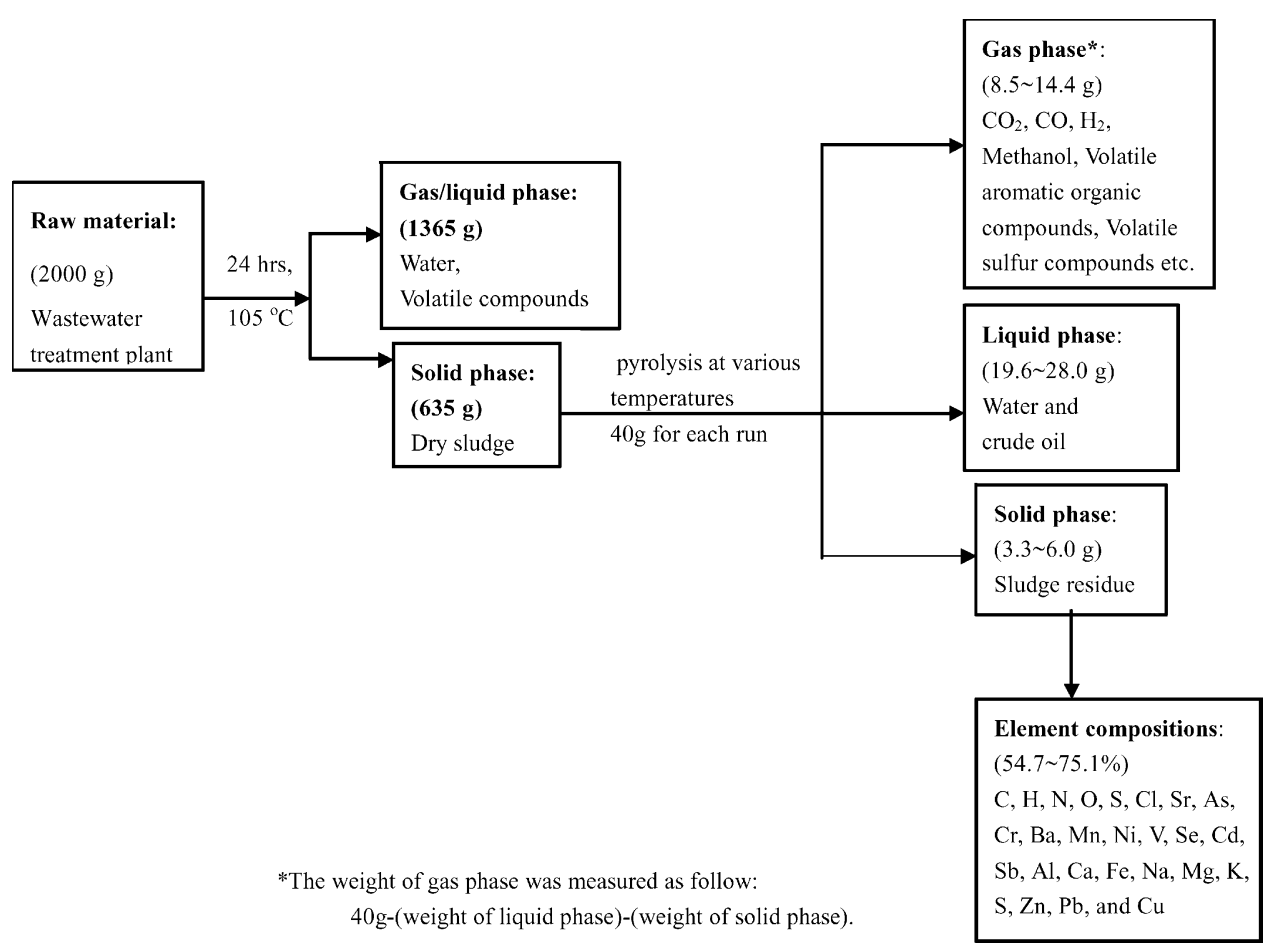

Fig. 2. Mass balance of sludge in drying and pyrolysis process.

smaller micropore structure. The amount of adsorbed nitrogen indicates the adsorption capacity of the pyrolytic residue; pyrolytic temperatures greater than $800^{\circ} \mathrm{C}$ correspond to a higher adsorption capacity. More mesopores and micropores are developed (Table 2).

According to the IUPAC classification, the pore can be divided into three clusters: such as a macropore (pore diameter is larger than $500 \AA$ ), mesopore (pore diameter is between 20 to $500 \AA$ ), and micropore (pore diameter is smaller than $20 \AA$ ). The results indicated that the mesopore contributed more than the macropore and micropore to the sludge pyrolytic residue. This sludge contains microorganisms, and therefore, the aggregated structure is not rigid like that of a lignin coconut shell or coal activated carbon structure. The polysaccharides are the major components of the microorganism secrete slime layer (Talaro et al., 1999) and produce a micropore size. In general, the cell wall of the microorganism is composed of peptidoglycans $(N$ acetyl muramic acid, $N$-acetyl glucosamine, and amino acid, etc.) (Talaro et al., 1999). The polysaccharide bond energy is lower than that of peptidoglycan. The polysaccharides are volatilized at the lower pyrolytic temperatures and form macropores and mesopores. When the pyrolytic temperature was higher than $700-800^{\circ} \mathrm{C}$, the peptidoglycan cracked and formed the mesopore and micropore.
The results indicated that the shorter the pyrolytic time, the larger is the macropore contribution to the pore structure. The water and easier volatile molecules in the mucous membrane and cell were vaporized to generate the macropore during the initial stage of the pyrolytic process. As the pyrolytic time and temperature increased, the cell wall cracked to generate both mesopore and micropore. Figure 4 shows the pore size distribution of the pyrolytic residue. Table 2 indicates that the micropore was developed at 800 and $900^{\circ} \mathrm{C}$. The process times were from 25 to $60 \mathrm{~min}$, and from 5 to $10 \mathrm{~min}$, respectively. When the pyrolytic time was too short, the micropore could not develop, but when the time was too long, the micropore could be destroyed. Therefore, the optimal pyrolytic times for micropore formation at 800 and $900^{\circ} \mathrm{C}$ were in the vicinity of 25 and $10 \mathrm{~min}$.

Conceptual model of pore development. In spite of pyrolysis conditions, the pyrolysis residues inherited some physical structure from the raw materials tissue. The fact that active sludge from biological wastewater treatment is a cluster of bacteria makes it reasonable to deduce the pore characters of pyrolysis residue from bacteria cell structure. The typical aerobic heterotrophic bacteria in activated sludge are Psudomonas (Gram( -$)$ ), Flavobacterium $(\operatorname{Gram}(-))$, Bacillus $(\operatorname{Gram}(+))$, Arthrobacter $(\operatorname{Gram}(+))$, etc (Bitton, 1999). Bacteria are small 


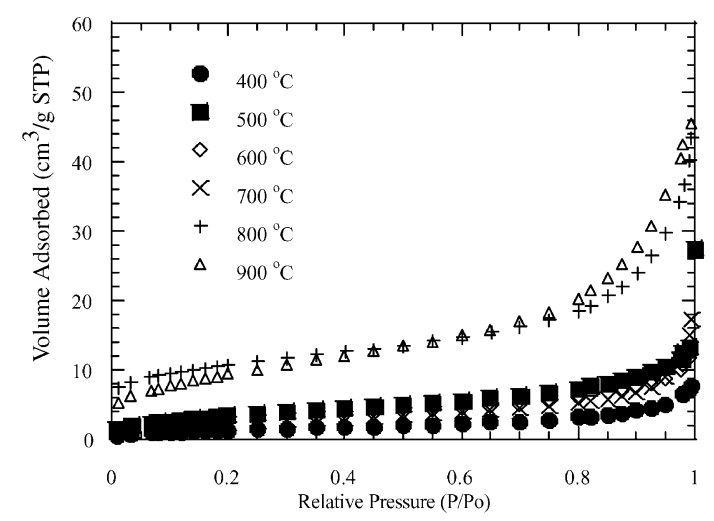

Fig. 3. Nitrogen adsorption isotherm for various pyrolytic temperatures.

rods, cocci or filament, having a general diameter in micrometers. All bacteria, except Mycoplasma, have a porous, rigid and high tensile strength cell wall that consists of murein, a unique type of peptidoglycan. The bulk of the Gram (+) bacteria cell wall is a thick, homogeneous sheath of peptidoglycan ranging from 20 to $80 \mathrm{~nm}$ in thickness. Gram $(-)$ bacteria have a thinner peptidoglycan ranging from 8 to $11 \mathrm{~nm}$ in thickness under lipid outer membrane (Talaro et al., 1999).

Peptidoglycan is a polymer of disaccharides (a glycan) cross-linked by short chains of amino acids (peptides). The glycan backbone is made up of alternating molecules of $\mathrm{N}$-acetylglucosamine (NAG) and $\mathrm{N}$-acetylmuramic acid (NAM) connected by a $\beta$ 1,4-glycoside bond. The 3-carbon of NAM is substituted with a lactyl ether group connected to a peptide side chain that contains amino acids differing for different species (Todar, 1999). Molecular simulation used a molecular mechanical Molecular mechanics-2 (MM2) mechanis method to calculate the size of the peptidoglycan mesh (Burkert and Allinger, 1982). The results revealed that the distance between two tetrapeptides was about $10-11 \AA$ for both species. The distance between two glycan backbones was about $10-11 \AA$ for $E$. coli and about $25 \AA$ for $S$. aureus. Figure $5(\mathrm{c})$ is a schematic diagram of the peptidoglycan sheet of $S$. aureus. The thickness of a single sheet was about $10-11 \AA$ for both $S$. aureus and E. coli.

Figure 5 indicates the conceptual model of pore development during the sludge pyrolysis process. The dry bacterium (Fig. 5(a)) is imaged as a tiny hollow sphere with a thick rigid murein shell. The vaporization of inner small molecular contents (water vapor, low molecular weight compounds, etc.) should crack the cell wall to form pores (Fig. 5(b)) thousands of Angstroms (macropore) in diameter, firstly, when it was heated under an oxygen-free atmosphere. As the temperature increased,

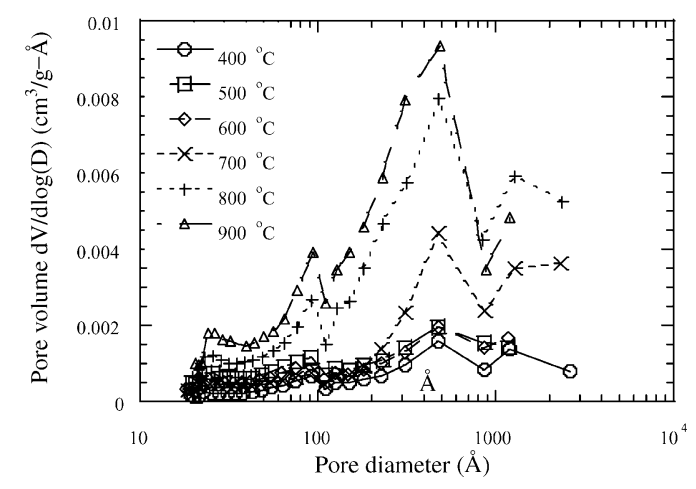

Fig. 4. Pore size distribution of sludge pyrolytic residue.

the coking of the carbohydrates broke the glycoside bond of the glycan backbone that sectioned the cell wall as slice (Fig. 5(d)). Fragments with a cell wall thickness of several hundred Angstroms piled up and fused to form pores of several hundred Angstroms in diameter (macropore and mesopore). When the temperature was high enough, the amide bonds may break down. Peptide chains lengths of several tens of Angstroms tangled to form pores (Fig. 5(e)) several tens of Angstroms in diameter (mesopore). When the pyrolysis temperature was higher than $700^{\circ} \mathrm{C}$, the bond between L-Ala, D-Glu, L-Lys and D-Ala broke to form the pore (Fig. 5(f)) of several Angstroms (micropore).

\section{CONCLUSIONS}

Results of element compositions indicated that carbon, hydrogen, and nitrogen concentrations were reduced as pyrolytic temperatures increased. The sulfur concentration, however, increased as the pyrolytic temperature increased. The ICP-AES and ICP-MS results indicated that the pyrolysis process concentrated the $\mathrm{Al}$, $\mathrm{Ca}, \mathrm{Fe}, \mathrm{Mg}, \mathrm{K}, \mathrm{Cu}, \mathrm{Sr}$, and $\mathrm{Sb}$. The pore size distribution analysis indicated that the pyrolytic residue of the biosludge was a mesopore. The highest BET surface area was obtained when the temperature and time were in the vicinity of $800^{\circ} \mathrm{C}$ and $30 \mathrm{~min}$. The optimal pyrolytic conditions for micropore formation were in the vicinity of $800^{\circ} \mathrm{C}$ for $30 \mathrm{~min}$ and $900^{\circ} \mathrm{C}$ for $10 \mathrm{~min}$. The results indicated that the bio-sludge could be an adsorbent resource under controlled pyrolytic temperature and time. The length of the molecular bond is used in the conceptual model to describe the development of pore volume. In a further study, we hope to modify the pyrolysis condition and treat the pyrolytic residue with chemicals to develop the pore volume to be an adsorbent. 


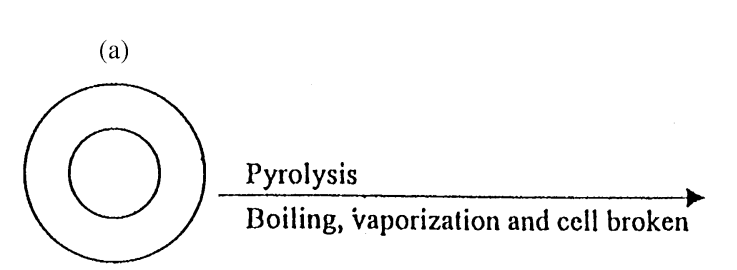

Gram (+), (-)

Bacteria Cell
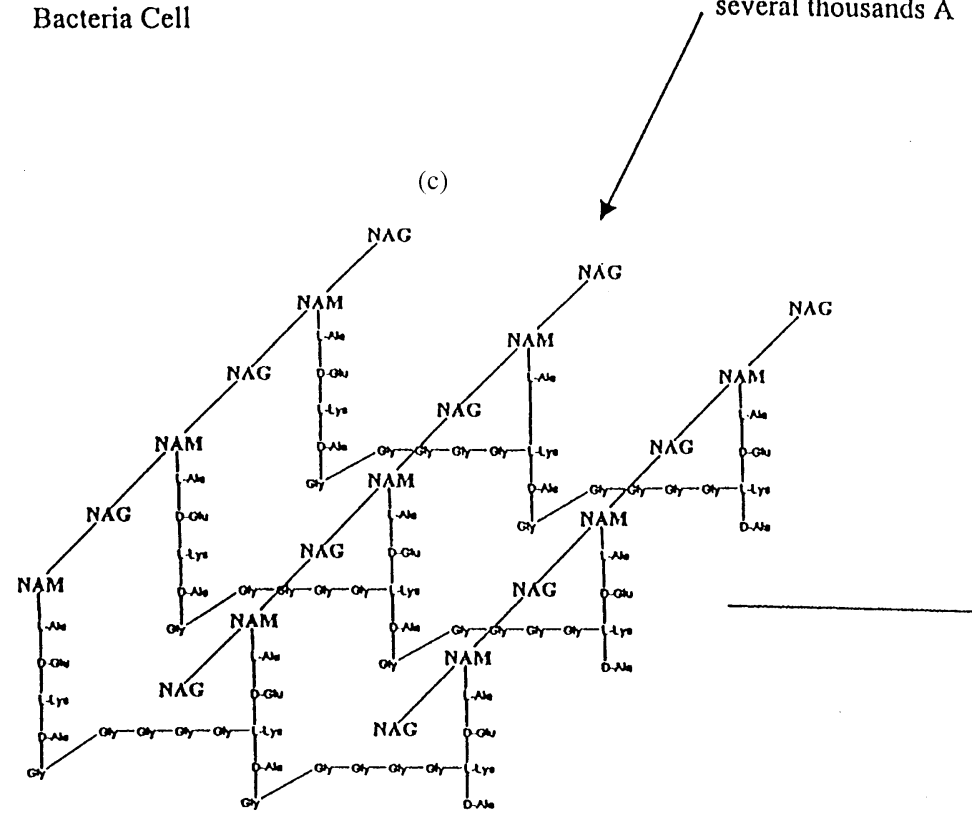

Cell wall structure

(b)

Cell wall

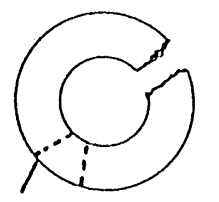

Pore diameter is about several thousands A

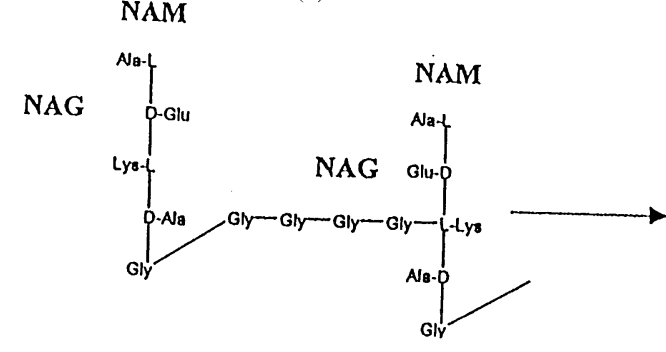

Bond of NAM and L-Ala is broken.

Pore diameter is about several decades A.

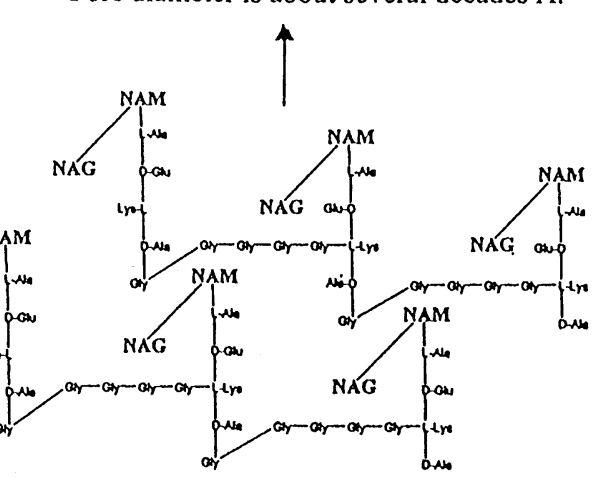

Bond of NAM and NAG is broken by pyrolysis. Pore diameter is about several hundreds $\AA$.

(d)

Fig. 5. Conceptual model of pore development for sludge pyrolysis. 
Acknowledgements - The authors express their sincere thanks to the National Science Council, Taiwan, ROC (Contract No. NSC 89-2211-E-242-006) and the Ministry of Education for the financial support of this study.

\section{REFERENCES}

Barrett E. P., Joyner L. S. and Halenda P. P. (1951) The determination of pore volume and area distributions in porous substances. I. computations from nitrogen isotherm. J. Am. Chem. Soc. 73, 373-380.

Bayer E. and Kutubuddin M. (1987) In Low Temperature Conversion of Sludge and Waste to Oil, eds K. J. ThomeKozmiensky and U. Loll, pp. 314-318. EF Verlag, Berlin.

Bitton G. (1999) Wastewater Microbiology, 2nd ed. pp. 96 97, 187, Wiley, New York.

Bridle T. R. (1982) Sludge-derived oil: wastewater treatment implications. Environ. Tech. Lett. 3, 151-156.

Brubauer S., Emmett H. P. and Teller E. (1938) Adsorption of gas in multimolecular layers. J. Am. Chem. Soc. 60 , 309-319.

Burkert U. and Allinger N. L. (1982) Molecular Mechanics. ACS, Washington, DC, USA.

Chiang P. C. and You J. H. (1987) Use of sewage sludge for manufacturing adsorbents. Can. J. Chem. Eng. 65, 922.

Dumpelmann R., Richarz W. and Stammbach M. R. (1991) Kinetic studies of the pyrolysis of sewage sludge by tga and comparison with fluidized beds. Can. J. Chem. Eng. 69, 953-922963.
Harkins W. D. and Jura G. (1944) Surfaces of solids XIII: a vapor adsorption method for the determination of the area of a solid without the assumption of a molecular area and the areas occupied by nitrogen and other molecules on the surface of a solid. J. Chem. Phys. 66, 1366-1373.

Kaminsky W. (1989) Pyrolysis von biomasse. Chem. Ing. Tech. 61, 775-782.

Kim B. R., Kalis E. M., Salmeen I. T., Kruse C. W., Demir I., Carlson S. L. and Rostam-Abadi M. (1996) Evaluation paint-sludge char for adsorption of selected paint solvents. J. Environ. Eng. 122(6), 532-539.

Lippens B. C. and de Boer J. H. (1965) Studies on pore system in catalysts V. the t method. J. Catal. 4, 319-323.

Lu G. Q., Low C. F., Liu C. Y. and Lua A. C. (1995) Surface area development of sewage sludge during pyrolysis. Fuel 74(3), 344-348.

Piskorz J., Scott D. S. and Westerberg. (1986) Flash pyrolysis of sewage sludge. I\&EC Process Design Dev. $25,265-270$.

Taiwan Environmental Protection Agency (1999) Workshop of Wastewater Treatment Technology and Management System- Sludge Treatment, Reduction, and Emergency System, Taipei, Taiwan, p. 70 (in Chinese).

Talaro Kathleen P. and Talaro A. (1999) Foundations in Microbiology Basic Principles. pp. 38-45, 88-100. McGraw-Hill, Boston.

Todar K. (1999) Structure and Function of Procaryotic Cells. http://www.bact.wisc.edu.tw/ $/$ bact303 $\backslash \backslash$ Structure http:// www.bact.wisc.edu.tw/ $/$ bact $303 \backslash$ structure. 